\title{
Sequence Characterization of Ovine MHC Class II (DRB I Gene) in Indian Sheep Breeds
}

\author{
Kush Shrivastava ${ }^{1}$, Pushpendra Kumar ${ }^{1 *}$, Mohd. Faheem Khan ${ }^{1}$, Shankar Dayal ${ }^{1}$, \\ Nihar Ranjan Sahoo', Rebeka Sinha ${ }^{1}$, Om Prakash ${ }^{1}$, Amit Kumar ${ }^{1}$, Manjit Panigrahi', \\ Anuj Chauhan', Bharat Bhushan', Arvind Prasad ${ }^{2}$, A. Nasir ${ }^{2}$ and B.H.M. Patel ${ }^{3}$ \\ ${ }^{1}$ Division of Animal Genetics, ${ }^{2}$ Division of Parasitology, ICAR - Indian Veterinary Research \\ Institute, Izatnagar, Bareilly, U.P., India \\ ${ }^{3}$ LPM Section, ICAR - Indian Veterinary Research Institute, Izatnagar, Bareilly, U.P. \\ *Corresponding author
}

\begin{tabular}{|c|c|}
\hline & B S T R A T \\
\hline Keywords & \multirow{4}{*}{$\begin{array}{l}\text { The major histocomtability complex in sheep is also called as Ovar- MHC and is a central } \\
\text { molecule for antigen presentation coding for specialized antigen presenting glycoproteins. } \\
\text { Studies related to internal parasitic infestations and their association with genetic diversity } \\
\text { in MHC region has suggested that some alleles of MHC DRB gene might augment the } \\
\text { immune response against parasitic antigens and also may hamper parasitic fecundity inside } \\
\text { the host. The exon } 2 \text { of DRB } 1 \text { gene forms the part of antigen loading clamp of MHC and } \\
\text { hence carries the greatest importance in relation to disease resistant research. We } \\
\text { sequenced the target exon in four Indian sheep breeds, the sequences were submitted to } \\
\text { NCBI. The sequences were then studied using bioinformatic tools to ascertain its structural } \\
\text { features and phylogenetic relationship. Finally it was observed that the variation between } \\
\text { the sequences is majorly present in intronic region which forms an excellent marker to } \\
\text { study the inheritance of adjoining exon also. Variations within the exons were mostly } \\
\text { neutral and didn't reflect in secondary structure as well as there was no change in the } \\
\text { ligand binding site. }\end{array}$} \\
\hline $\begin{array}{l}\text { Ovine MHC DRB, } \\
\text { Exon 2, } \\
\text { Bioinformatics, } \\
\text { Disease resistance, } \\
\text { Sheep }\end{array}$ & \\
\hline Artic & \\
\hline $\begin{array}{l}\text { Accepted: } \\
\text { 06 June } 2018 \\
\text { Available Onli } \\
10 \text { July } 2018\end{array}$ & \\
\hline
\end{tabular}

\section{Introduction}

The major histocompatibility complex in sheep is also called as Ovar- MHC and is a central molecule for antigen presentation coding for specialized antigen presenting glycoproteins (Dukkipati et al., 2006). The MHC molecule is an important candidate gene for disease resistance studies in farm animals (Dukkipati et al., 2006). The MHC is a group of closely linked genetic loci that tend to inherit together. In sheep the MHC is divided into three subgroups class I, class II and class III. The class I region however is poorly defined for the presence of number loci, that range from 2 to 4 . The class II region however is much better characterized in sheep and consists of five loci viz., DR, DQ, DY, DM and DN/DO (Dukkipati et al., 2006). The loci DR and DQ are most important and have been extensively used in disease resistant studies in sheep (Hulme et al., 1991; 
Litchfield et al., 1993; Escayg et al., 1997; Shrivastava et al., 2015). The DR subgroup is further divided as DRA (coding for alpha chain of the peptide binding groove) and DRB (coding for beta chain of the peptide binding groove). The DRB loci is further divided into DRB1, DRB2, DRB3 and DRB4 regions among which DRB1 is coding and rest three are non coding genes (Dukkipati et al., 2006; Shrivastava et al., 2015). The DRB locus along with the DRA codes for the antigen binding groove of MHC therefore it displays a high degree of genetic variability to deal with variety of antigens (Tizzard, 2013). This diversity in its structure not only accounts for variety in antigens but also makes it a candidate gene for association studies especially involving disease / immune related traits (Li et al., 2010). Beside the high degree of polymorphism exhibited by DRB locus in sheep one major characteristic feature of DRB region is presence of microsatellite repeat region (Dukkipati et al., 2006). Because of its large size and presence of pseudogenes the full characterization of MHC gene is difficult. There are ample amount of MHC DRB sequences available of various sheep breeds from all over the world however data regarding sequence characterization in Indian sheep breeds is yet scanty. India possess a huge genetic diversity in sheep genetic resource consisting of 42 recognized sheep breeds (http://www.nbagr.res.in/). This high breed diversity is found scattered along 15 agro-climatic regions of the country (Kumar et al., 2003). There are reports suggesting presence of unique morphological, physiological, productive, reproductive and health traits in these breeds. Some breeds like Garole (Nimbkar et al., 2003), Magra, Bikaneri (Singh and Swarnkar, 2014) are known to possess inherent traits of being resistance to diseases especially to internal parasitic infestation that forms the major production and animal losses in sheep industry (Anonymous, 2012). Studies related to internal parasitic infestations and their association with genetic diversity in MHC region has suggested that some alleles of MHC DRB gene might augment the immune response against parasitic antigens and also may hamper parasitic fecundity inside the host (Dukkipati et al., 2006). Looking into these important facts we carried out sequencing and characterization of MHC DRB gene fragment in four sheep breeds of India viz., Muzaffarnagri, Chokla, Marwari and Malpura. The sequences were compared with existing sequences of major sheep breeds and were further analyzed on nucleotide and amino acid level using bioinformatic tools.

\section{Materials and Methods}

\section{DNA isolation and PCR amplification}

Four Indian sheep breeds viz., Muzaffarnagri, Chokla, Marwari and Malpura were selected for the current study. DNA was isolated from blood using the standard Sambrook and Russell (2001) method, quality checked on 0.8 $\%$ agarose gel electrophoresis and nanodrop spectrophotometer. Only the good quality DNA showing intact band and $\mathrm{OD}_{260 / 280}$ value ranging from 0.7-0.8 were further used for PCR amplification. For amplification of desired sequence (MHC DRB exon 2) oligonucleotide primers were used as reported by Amills et al., (1998). Template DNA was amplified using standard PCR mix with $80-$ $100 \mathrm{ng}$ of genomic DNA, $12.5 \mu \mathrm{l}$ of PCR master mix (ThermoFisher Scientific), 10 pmoles of each primer (forward and reverse) and nuclease free water to make volume $25 \mu \mathrm{l}$. The contents were thoroughly mixed and set up in a thermocycler (ABI thermocycler) with the following amplification programme; initial denaturation at $95^{\circ} \mathrm{C}$ for $5 \mathrm{~min}$, followed by 39 cycles of denaturation at $94^{\circ} \mathrm{C}$ for $1 \mathrm{~min}$, annealing at $59.0^{\circ} \mathrm{C}$ for $45 \mathrm{~s}$ and extension at $72^{\circ} \mathrm{C}$ for $1 \mathrm{~min}$, and finally the last extension at $72^{\circ} \mathrm{C}$ for $5 \mathrm{~min}$. The PCR products were 
checked by agarose gel electrophoresis using $1.0 \%$ agarose gel in $1 \mathrm{X}$ Tris-borate-EDTA buffer at $6 \mathrm{~V} / \mathrm{cm}$ for $1 \mathrm{~h}$.

\section{Sequence analysis}

Amplified PCR products were then cleaned using GeneJet PCR purification kit (Thermo Scientific) and rechecked using $1.0 \%$ agarose gel electrohporesis. The samples were sent for sequencing by automated sequencer via outsourcing. The raw sequences were first assembled using bioedit and DNA Baser programme. The final assembled sequences were then aligned using Clustal $\mathrm{W}$ in MEGA 6.0 software. Related sequences were then downloaded in FASTA formats from NCBI using BLAST tool. Further analysis of sequences was carried out by MEGA 6.0 and DNAStar. For protein structure and binding site prediction two online servers viz., Phyre 2 (http://www.sbg.bio.ic.ac.uk/phyre2/html/page .cgi?id=index) (Kelley et al., 2015) and 3D ligand site (http://www.sbg.bio.ic.ac.uk/ 3dligandsite/) (Wass et al., 2010) were used.

\section{Results and Discussion}

The raw sequences obtained were assembled using Bioedit and DNA baser programme. The final assembled sequences were submitted to NCBI database and accession numbers were assigned to them as KT878759 (Marwari sheep), KT878758 (Malpura sheep), KT764074 (Chokla sheep; Haplotype 1), KT764075 (Chokla sheep; Haplotype 2), KT764076 (Chokla sheep; Haplotype 3), KT764077 (Chokla sheep; Haplotype 4), KT781587 (Muzaffarnagri sheep; Haplotype A), KT781588 (Muzaffarnagri sheep; Haplotype B). On the basis of dissimilarities after alignment the haplotypes were made, total four haplotypes were found in Chokla sheep designated from 1 to 4 , and two were found in Muzaffarnagri sheep designated as A and B. There were total 98 dissimilarities between the sequences including the exons and introns, when the introns were trimmed and only exons were analysed the total sites of disagreement between the sequences was 48 , which shows that a major portion of the variation was present in introns, specially in the repeat region. For comparison, sequences of the same region from Western sheep breeds, Merino (Acc No. U00227), Ramboullet (Acc. No. EU176819) and Texel (Acc. No. U00232) were downloaded from NCBI. The sequences were then aligned using Clustal W in MEGA 6.0 (Fig. 1). The exon two of MHC DRB spanned from $8^{\text {th }}$ base pair to $277^{\text {th }}$ base pair (bp) followed by the intron 2 region. The characteristic feature of the sequence was the tandem repeats present in intron 2 consisting of GT and AG dinucleotide repeats (Fig. 1). This repeat region is actually a microsatellite locus which is a prominent feature of introns in ovine MHC gene. A heat map was generated using heatmapper (Babicki et al., 2016) to ascertain the pair-wise distance between the sequences. Within the Indian breeds, haplotypes of Chokla breed 3 and 2 were close in similarity and haplotypes 4 and 1 were distant apart. In Muzaffarnagri sheep, both the haplotypes were distant and the haplotype A was closer to Chokla haplotype 1 and 4 (Fig. 2).

Amino acid comparison was only done between the studied Indian breeds. The nucleotide codons were translated and aligned using MEGA 6.0. The total length of amino acid chain was 89 amino acid long with 26 sites of disagreement between the sequences (Fig. 3), and amino acid composition analysis showed maximum percentage of arginine (12.08\%) followed by glutamic acid (11.66\%) and methionine was found least (nil) (Table 1). The overall average evolutionary divergence was low i.e., 0.13 among the sequences. The secondary structure prediction using phyre2 server showed that all the sequences contained a majority of beta sheet 
structure, ranging from $38 \%-44 \%$. The secondary structures were then used to predict possible ligand binding site prediction and it was found that in all the sequences, amino acid serine (at position 83) and glutamine (at position 87) were having the highest confidence (Fig. 4).

Fig.1 Nucleotide alignment of all the studied sequences as done by Mega 6.0

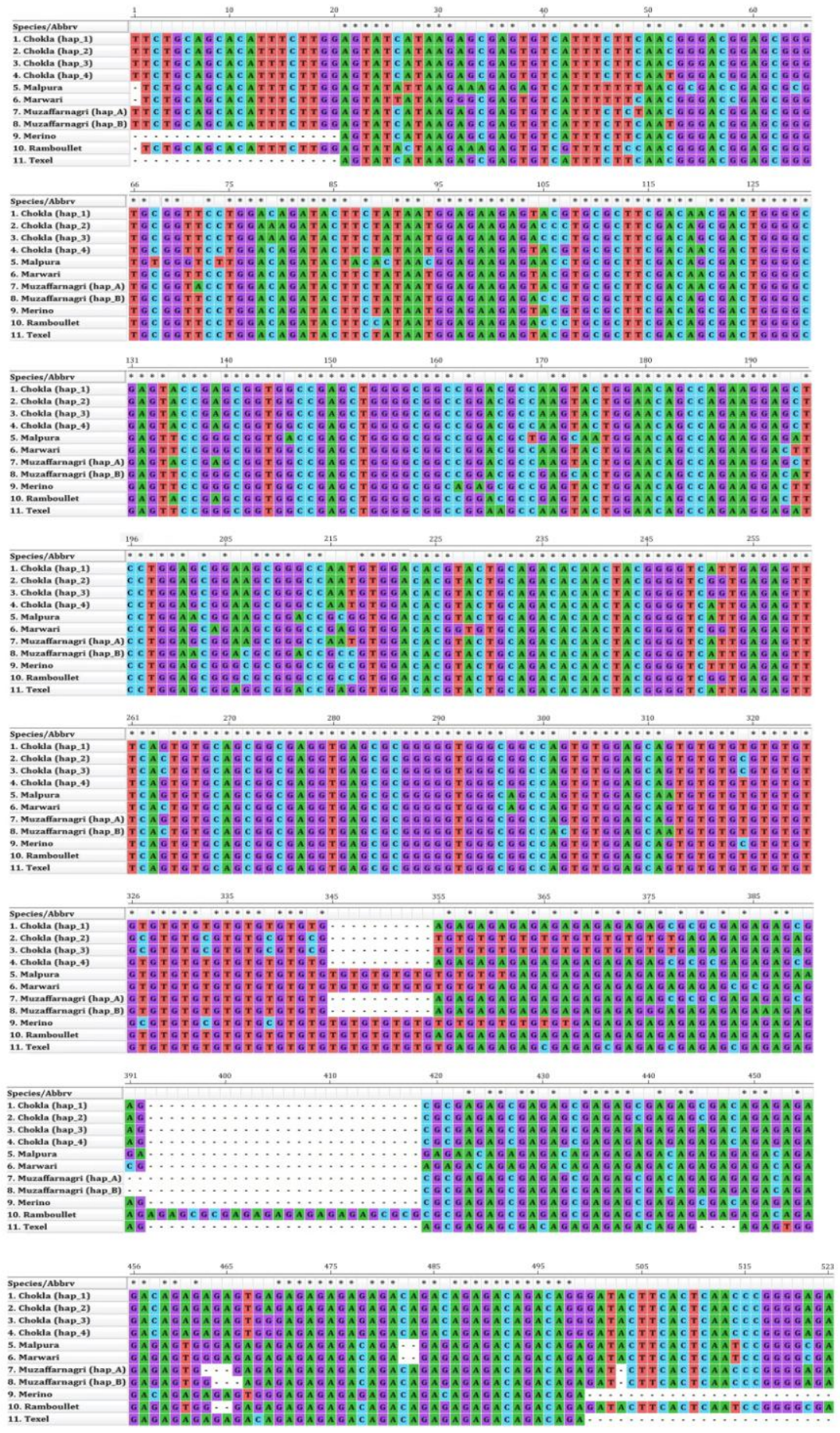


Fig.2 Heat map of pair wise comparison of the studied sequences done by Heat mapper. Colour from blue to yellow indicates similarity scale, blue being the indicator for similarity

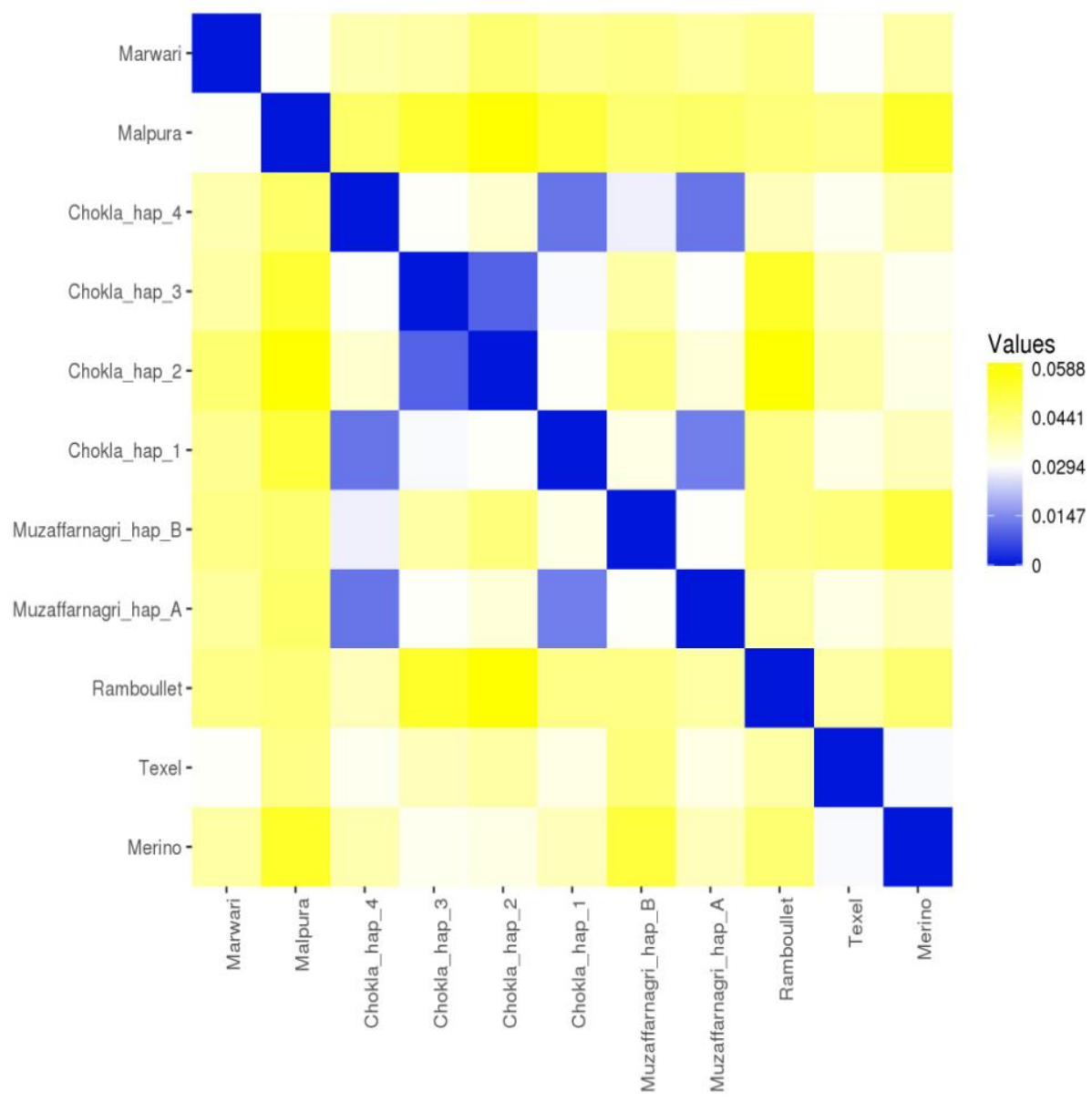

Fig.3 Amino acid alignment of the translated exon portion of Indian sheep breeds as done by Mega 6.0

\begin{tabular}{|c|c|}
\hline & $\% *$ \\
\hline 1 & IGEYRAVAEL GRPDAKYWNSQKELLERKRANVDTYCRHNYGIESFSVQRR \\
\hline & VRFLERYFYNGEETLRFDSDWGEYRAVAELGRPDAKYWNSQKELLE \\
\hline p.3 & FNGTERVRF LERYFYNGEETLRFDSDWGEYRAVAELGRPDAKYW \\
\hline hokla & HFLEYHKSECHFFNGTERVRFLDRYFYNGEEYVRFDNDWGEYRAVAELGRPDAKYWNSQKELLERKRANVDTI \\
\hline & YNGFEY URFN \\
\hline & HFLEY \\
\hline pura & HFLEYIKKESHFFNATERVWVLDRYTNGEENLRFDSDWGEFRAVTELGRPDAEWW \\
\hline arwari & HFLEYKGECHFFNGTERVRFLDRFYNGEEYVRFDNDWGERAVAELGRPDAKYWNSQKDFLEQKRAEVDVCRHNYGGESFTVQR \\
\hline
\end{tabular}


Fig.4 (A) Secondary protein structure prediction of the translated amino acids; (i) Chokla hap 1, (ii) Chokla Hap 2, (iii) Chokla Hap 3, (iv) Chokla Hap 4, (v) Malpura, (vi) Marwari, (vii) Muzaffarnagri Hap A and (viii) Muzaffarnagri Hap B; (B) Ligand binding site prediction of translated amino acid sequence taking Malpura breed as representative

(A)

HFLEYHKSE CHFF NGTERVRFL DRYFYNGEEYVRF DNDWGEYRAVAEL GRP DAKY WNSQKELLERKRANVDTYCRHY GVI ESF SVQRR

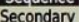

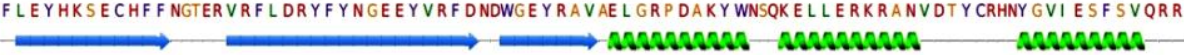
Secondary
structure (i)

HFLEYHKSECHFF NGTERVRFLERYFYNGEETLRF DSDWGEYRAVAEL GRP DAKY WNSQRELLERKRANVDTYCRHNYGVGESFTVQRR Sequen Secondary $\stackrel{\longrightarrow}{\longrightarrow}$ (ii)

HFLEYHKSECHFF NGTERVRFLERYFYNGEETLRF DSWGEYRAVAEL GRPDAKY WNSQRELLERKRANVDTYCRHNYGVGESFTVQRR Sequen Secondar
structure $\longrightarrow$

(iii)

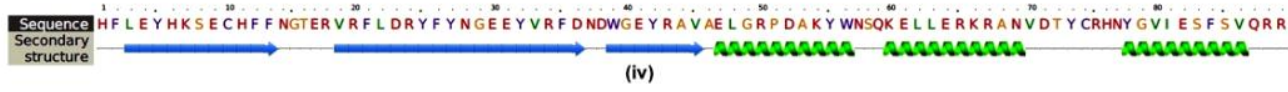

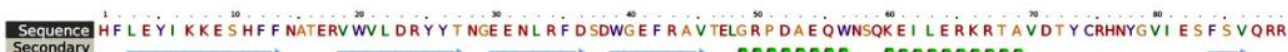
Seconda

(v)

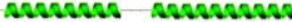

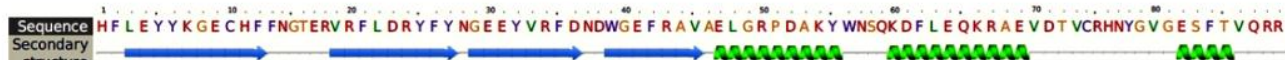

(vi)

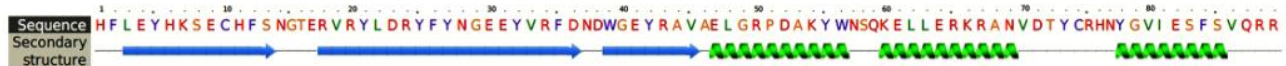

(vii)

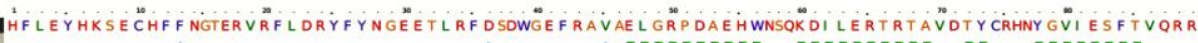

(B)

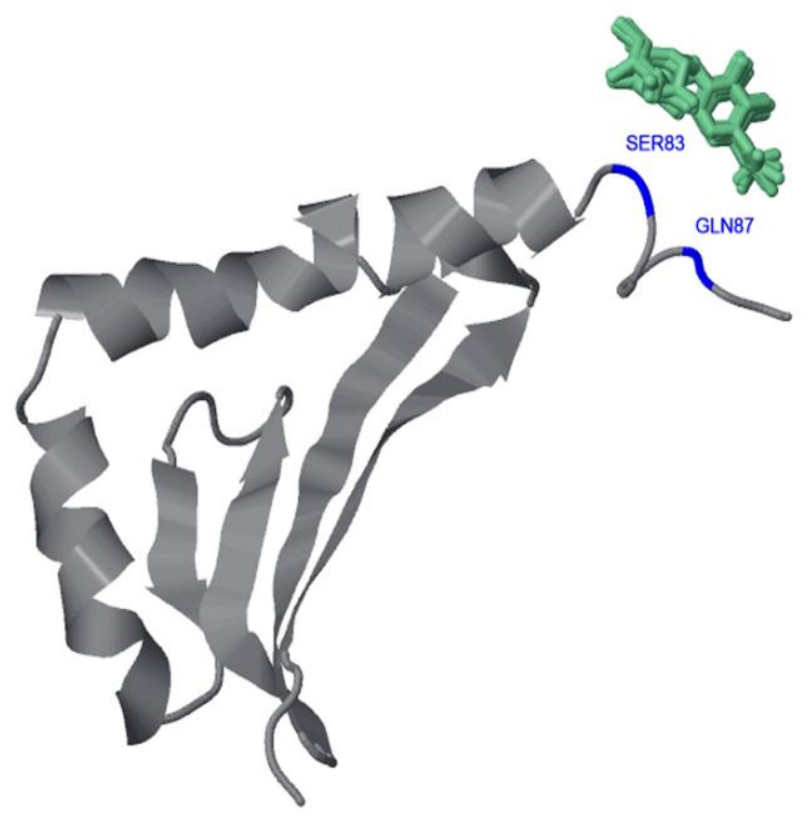


Table.1 Amino acid composition of all the studied sequences (values are expresses as percentage)

\begin{tabular}{|c|c|c|c|c|c|c|c|c|c|c|c|c|c|c|c|c|c|c|c|c|}
\hline Name & Ala & Cys & Asp & Glu & Phe & Gly & His & Ile & Lys & Leu & Met & Asn & Pro & Gln & Arg & Ser & Thr & Val & Trp & Tyr \\
\hline Marwari & 4.49 & 2.25 & 6.74 & 11.24 & 10.11 & 7.87 & 3.37 & 0.00 & 4.49 & 4.49 & 0.00 & 5.62 & 1.12 & 3.37 & 11.24 & 2.25 & 3.37 & 7.87 & 2.25 & 7.87 \\
\hline Malpura & 4.49 & 1.12 & 5.62 & 12.36 & 6.74 & 4.49 & 3.37 & 3.37 & 4.49 & 5.62 & 0.00 & 5.62 & 1.12 & 3.37 & 11.24 & 5.62 & 5.62 & 6.74 & 3.37 & 5.62 \\
\hline Chokla Hap 4 & 4.49 & 2.25 & 5.62 & 11.24 & 7.87 & 5.62 & 4.49 & 1.12 & 4.49 & 5.62 & 0.00 & 6.74 & 1.12 & 2.25 & 12.36 & 4.49 & 2.25 & 6.74 & 2.25 & 8.99 \\
\hline Chokla Hap 3 & 4.49 & 2.25 & 4.49 & 12.36 & 7.87 & 6.74 & 4.49 & 0.00 & 4.49 & 6.74 & 0.00 & 5.62 & & 2.25 & & 4.49 & 4.49 & 5.62 & 25 & 7.87 \\
\hline Chokla Hap 2 & 4.49 & 2.25 & 4.49 & 12.36 & 7.87 & 6.74 & 4.49 & 0.00 & 4.49 & 6.74 & 0.00 & 5.62 & 1.12 & 2.25 & 12.36 & 4.49 & 4.49 & 5.62 & 2.25 & 7.87 \\
\hline Chokla Hap 1 & 4.49 & 2.25 & 5.62 & 11.24 & 7.87 & 5.62 & 4.49 & 1.12 & 4.49 & 5.62 & 0.00 & 6.74 & 1.12 & 2.25 & 12.36 & 4.49 & 2.25 & 6.74 & 2.25 & 8.99 \\
\hline Muzaffarnagri Hap A & 4.49 & 2.25 & 5.62 & 11.24 & 5.62 & 5.62 & 4.49 & 1.12 & 4.49 & 5.62 & 0.00 & 6.74 & 1.12 & 2.25 & 12.36 & 5.62 & 2.25 & 6.74 & 2.25 & 10.11 \\
\hline Muzaffarnagri Hap B & 4.49 & 2.25 & 6.74 & 11.24 & 8.99 & 5.62 & 5.62 & 2.25 & 2.25 & 5.62 & 0.00 & 4.49 & 1.12 & 2.25 & 12.36 & 4.49 & 6.74 & 5.62 & 2.25 & 5.62 \\
\hline Average & 4.49 & 2.11 & 5.62 & 11.66 & 7.87 & 6.04 & 4.35 & 1.12 & 4.21 & 5.76 & 0.00 & 5.90 & 1.12 & 2.53 & 12.08 & 4.49 & 3.93 & 6.46 & 2.39 & 7.87 \\
\hline
\end{tabular}


The MHC class II DRB 1 gene carries immense importance as it forms the antigen binding cleft and presents these exogenous peptides to the $\mathrm{T}$ cell receptors of $\mathrm{CD} 4+$ helper $\mathrm{T}$ cells (Germain and Margulies, 1993). The DRB gene codes for the beta $(\beta)$ chain of the MHC heterodimer and at least four DRB loci has been identified i.e., DRB1 which is the coding gene and DRB2, DRB3, DRB4 (non coding) (Dukkipati et al., 2006). The region has characteristic GT and AG repeat sequence, which we were able to identify, this microsatellite (or simple sequence repeat) region forms an excellent marker for studying the inheritance of this gene and its association with disease resistance traits in sheep (Buitkamp et al., 1994; Schwaiger et al., 1995; Charon et al., 2002; Sayers et al., 2005; Marshall et al., 2009; Castillo et al., 2011). The exon region spanning from $8^{\text {th }}$ base pair to $277^{\text {th }}$ also forms a potential region for SNP (single nucleotide polymorphism) studies. As we have observed there are variations at amino acid level, however, there was no change in ligand binding site affinity and a less amount of variation was seen at secondary structure level. This confers that variations at exons may not be necessarily translated into proteins and even the variations within the same species in not affecting the predicted structure. Therefore, this variation may have their effect during binding or switching the structure of antigen loading clamp as per the exogenous peptide. However, at nucleotide level the exon regions showed 48 points of dissimilarities between the sequences, this illustrates that the exon region forms a potential candidate for PCR - RFLP studies (Brujeni, et al., 2009; Jamshidi et al., 2011; Shrivastava et al., 2015; Ilhan et al., 2016). The region has been extensively studied for association of polymorphism at restriction cutting sites with resistance/ susceptibility to diseases viz., hydatidosis in Kazakh sheep ( $\mathrm{Li}$ et al., 2010), echinococcosis in Chinese merino sheep (Shen et al., 2014), faecal egg count in Iranian Ghezel sheep (Valilou et al., 2015).

In conclusion, the importance of ovine MHC class II, DRB region is unequivocal. The presence of repeat region in introns was a constant feature among different breeds. There was ample amount of variation within the sequence (in both intron and exon) that can be tapped in association studies. The variation however, was not carried in protein secondary structure and in ligand binding site indicating that it will be more beneficial to study the variability of intronic region, which can be better utilized to study the inheritance of whole region (i.e., intron and the adjacent exon).

\section{Acknowledgment}

The authors are thankful to the Director, IVRI, Izatnagar, Bareilly, for providing necessary facilities to carry out this research work. The first author is also thankful to Indian Council of Agricultural Research for providing necessary financial assistance in the form of fellowship during the study.

\section{References}

Amills, M., Ramiya, V., Norimine, J. and Lewin, H. A. 1998. The major histocompatibility complex of ruminants. Rev. Sci. Tech. 17 (1): 108-120.

Anonymous. 2012. Summary record of meeting of experts on Integrated Parasitic Disease Control Programme, Krishi Bhavan, 15th Oct, New Delhi.

Babicki, S., Arndt, D., Marcu, A., Liang, Y., Grant, J.R., Maciejewski, A. and Wishart, D.S. 2016. Heatmapper: web-enabled heat mapping for all. Nucleic Acids Res. doi:10.1093/nar/gkw419. 
Brujeni, N., Emam, M., Mahmoudzadeh, H., Hamedmonfared, E., Talebnia Jahromi, R. and Rezaei, H. 2009. Typing of Ovar-DRB1 second exon with PCR-RFLP technique in Iranian Shaul Sheep. Iran. J. Vet. Res. 10 (3): 250-254.

Buitkamp, J., Gostomski, D., Schwaiger, F.W., Stear, M.J. and Epplen, J.T. 1994 Association between the ovine major histocompatibility complex DRB1 gene and resistance to Ostertagia circumcincta infestation. Anim. Genet. 25: 59-60.

Castillo, J.A.F., Medina, R.D.M., Villalobos, J.M.B., Gayosso-Vázquez, A., UlloaArvízu, R., Rodríguez, R.A., Ramírez, H.P. and Alonso Morales, R.A. 2011. Association between major histocompatibility complex microsatellites, fecal egg count, blood packed cell volume and blood eosinophilia in Pelibuey sheep infected with Haemonchus contortus. Vet. Parasitol. 177 (3-4): 339-344.

Charon, K.M., Moskwa, B., Rutkowski, R., Gruszczynska, J. and Swiderek, W. 2002. Microsatellite polymorphism in DRB1 gene (MHC class II) and its relation to nematode faecal egg count in polish heath sheep. J Anim. Feed Sci. 11: 47-58.

Dukkipati, V.S.R., Blair, H.T., Garrick, D.J. and Murray, A. 2006. 'Ovar-Mhc' Ovine major histocompatibility complex: Role in genetic resistance to diseases. New Zealand Veterinary Journal. 54 (4): 153-160.

Escayg, A.P., Hickford, J.G.H., Bullock, D.W. 1997. Association between alleles of the ovine major histocompatibility complex and resistance to footrot. Research in Veterinary Science. 63: 283-287.

Germain, R.N. and Margulies, D.H. 1993. The biochemistry and cell biology of antigen processing and presentation. Annual Review of Immunology. 11: 403-450.

Hulme, D.J., Windon, R.G., Nicholas, F.W., Beh, K.J. 1991. Association between MHC class II RFLP and Trichostrongylus resistance. In: Gray, G.D. and Woolaston, R.R. (Eds), Breeding for Disease Resistance in Sheep. Wool Research and Development Corporation, Australia, Pp 115-120.

Ilhan, F., Keskin, I. and Tozluca, A. 2016. Identification of genetic variation in the major histocompatibility complex gene region in Turkish sheep breeds. South African Journal of Animal Science. 46 (No. 4): 366-372.

Jamshidi, R., Brujeni, G.N., Derakhshandeh, A. and Talebnia, R. 2010. Exon 2 ovar-DRB1 gene polymorphism in the Iranian Sangsari sheep. Int. J. Vet. Res. 5 (1): 59-62.

Kelley, L.A., Mezulis, S., Yates, C.M., Wass, M.N., and Sternberg, M.J.E. 2015. The Phyre2 web portal for protein modeling, prediction and analysis. Nature Protocols. 10: 845-858.

Kumar, K.G., Kumar, P., Bhattacharya, T.K., Bhushan, B., Patel, A.K., Choudhary, V. and Sharma, A. 2003. Genetic relationship among four Indian breeds of sheep using RAPD-PCR. J. Appl. Anim. Res., 24: 177-183.

Li, R., Jia, B., Zhang, W., Zhao, Z., Shi, G., Shen, H., Peng, Q., Lv, L., Zhou, Q., and Du, Y. 2010. Analysis of the Relationship between MHC-DRB1 Gene Polymorphism and Hydatidosis in Kazakh Sheep. Asian-Aust. J. Anim. Sci. 23, (9): 1145 - 1151.

Litchfield, A.M., Raadsma, H.W., Hulme, D.J., Brown, S.C., Nicholas, F.W., Egerton, J.R. 1993. Disease resistance in Merino sheep. II. RFLPs in class II MHC and their association with 
resistance to footrot. Journal of Animal Breeding and Genetics. 110: 321-34.

Marshall, K., Maddox, J.F., Lee, S.H., Zhang, Y., Kahn, L., Graser, H.U., Gondro, C., Walkden-Brown, S.W. and Van der Werf, J.H.J. 2009. Genetic mapping of quantitative trait loci for resistance to Haemonchus contortus in sheep. Anim. Genet. 40(3): 262-272.

Nimbkar, C., Ghalasi, P.M., Swan, A.A., Walkden-Brown, S.W. and Kahn, L.P. 2003. Evaluation of growth rates and resistance to nematodes of Deccani and Bannur lambs and their crosses with Garole. Anim. Sci. 76: 505-515

Sambrook, J. and Russell, D.W. (2001). Molecular cloning a laboratory Manual. 3rd Edition. Cold Spring Harbor Laboratory Press, NY, USA.

Sayers, G., Hanrahan, J.P., Good, B., Ryan, M., Angles, J.M. and Sweeney, T. 2005. Major histocompatibility complex DRB1 locus: Its role in nematode resistance in Suffolk and Texel sheep breeds. Parasitology. 131 (3): 403-409.

Schwaiger, F.W., Gostomski, D., Stear, M.J., Duncan, J.L., McKellar, Q.A., Epplen, J.T. and Buitkamp, J. 1995. An ovine major histocompatibility complex DRB1 allele is associated with low faecal egg counts following natural, predominantly Ostertagia circumcincta infection. Int. J Parasitol. 25 (7): 815-822.
Shen, H., Han, G., Jia, B., Jiang, S. and Du, Y. 2014. MHC-DRB1/DQB1 Gene polymorphism and its association with resistance/susceptibility to cystic echinococcosis in Chinese Merino sheep. J Parasitol. Res. Article no. 272601: 1-7.

Shrivastava, K., Kumar, P., Sahoo, N.R., Kumar, A., Khan, M.F., Kumar, A., Prasad, A., Patel, B. H. M., Nasir, A., Bhushan, B. and Sharma, D. 2015. Genotyping of major histocompatibility complex Class II DRB gene in Rohilkhandi goats by polymerase chain reaction-restriction fragment length polymorphism and DNA sequencing. Veterinary World, 8(10): 1183-1188.

Singh, D. and Swarnkar, C.P. 2014. Influence of sheep breeds on the susceptibility to strongyle infection in Rajasthan. Ind. J. Ani. Sci., 84 (2): 120-126.

Tizzard, I. 2013. Veterinary Immunology. $9^{\text {th }}$ edition, Saunders, Elsevier Inc.

Valilou, R.H., Rafat, S.A., Notter, D.R., Shojda, D., Moghaddam, G. and Nematollahi, A. 2015. Fecal egg counts for gastrointestinal nematodes are associated with a polymorphism in the MHC-DRB1 gene in the Iranian Ghezel sheep breed. Frontiers in Genetics. 6 (105): 1-11.

Wass, M.N., Kelley, L.A. and Sternberg, M.J. 2010. 3DLigandSite: predicting ligand-binding sites using similar structures. NAR, 38(W): 469-473.

\section{How to cite this article:}

Kush Shrivastava, Pushpendra Kumar, Mohd. Faheem Khan, Shankar Dayal, Nihar Ranjan Sahoo, Rebeka Sinha, Om Prakash, Amit Kumar, Manjit Panigrahi, Anuj Chauhan, Bharat Bhushan, Arvind Prasad, A. Nasir and Patel, B.H.M. 2018. Sequence Characterization of Ovine MHC Class II (DRB I Gene) in Indian Sheep Breeds. Int.J.Curr.Microbiol.App.Sci. 7(07): 490499. doi: https://doi.org/10.20546/ijcmas.2018.707.060 